Les actes de colloques du musée du quai Branly Jacques Chirac

4 | 2014

Australian Aboriginal Anthropology Today: Critical Perspectives from Europe

\title{
Paintings, Publics, and Protocols: the early paintings from Papunya
}

Fred Myers

\section{(2) OpenEdition}

\section{Journals}

Electronic version

URL: http://journals.openedition.org/actesbranly/524

DOI: $10.4000 /$ actesbranly.524

ISSN: 2105-2735

Publisher

Musée du quai Branly Jacques Chirac

Electronic reference

Fred Myers, "Paintings, Publics, and Protocols: the early paintings from Papunya », Les actes de colloques du musée du quai Branly Jacques Chirac [Online], 4 | 2014, Online since 13 June 2014 connection on 08 September 2020. URL : http://journals.openedition.org/actesbranly/524 ; DOI : https://doi.org/10.4000/actesbranly.524

This text was automatically generated on 8 September 2020

(c) Tous droits réservés 


\title{
Paintings, Publics, and Protocols: the early paintings from Papunya
}

\author{
Fred Myers
}

1 I am taking the occasion of the musée du quai Branly's very recent exhibition of early Papunya paintings to talk today about the complex epistemological and political issues instantiated in the history of Papunya painting, raised by the contact between distinctive regimes of knowledge and value. It is partly a personal history and partly a story that appropriately enough, cannot be extricated from the web of relationships that define the representation and contemporary production of Aboriginal culture.

Western Desert acrylic paintings are objects made to move between cultures, created by Indigenous artists with introduced materials on permanent western surfaces, such as canvas, in order to express themselves and their culture to a non-Indigenous audience. The Papunya artists wanted people to know and understand that the paintings were Tjukurrtjanu ('from The Dreaming') - that their contents were not 'made up' - and they wanted the paintings to be valued because of their relationship to this sacred tradition. ${ }^{1}$ The paintings, we now understand, were political assertions of cultural value and particularly of their relationship to land in the face of the assimilating forces of government policy in that era. While the paintings have had an extraordinary trajectory, it has not been a simple one - because the protocols of viewing and knowing that are essential to their producers differ radically from those of the people who come to view them. It is widely understood that the paintings of Papunya Tula artists are contemporary expressions of ritual, mythological, musical and geographical knowledge - knowledge of what is frequently called Tjukurrpa in Pintupi and 'The Dreaming' in English - that was part of a complex gender-segregated initiatory cosmological system. The translation of such a system that distributes knowledge differentially into one that imagines freedom of access is always unstable. In the Indigenous system as it has existed in Central Australia, rights to know and perform different portions of stories distinguish those with a right to see or learn about these designs (for example, initiated men and sometimes, more particularly, those from a particular local group) from those who are still learning, and all of them from females (who 
have their own exclusive ritual traditions) anduninitiated males. In this 'revelatory' regime of value, control over the visual - over what can be seen and by whom - is central; the fundamental concern is to limit dispersal, to control the potential or manifestations of Tjukurrpa, objectifications of ancestral power identified with persons and groups. Aboriginal men of the Central and Western Deserts acquire knowledge of and rights to express these traditions through sequences of initiation and exchange. These rights were - and are - part of the significant identities that linked people throughout the region, as shareholders, if you will, in highly valued religious traditions.

3 It was (and is) this knowledge, and its design forms, that constituted the foundation of Western Desert acrylic painting and the imaginative inspiration for the painters. By 1971, Aboriginal people had been explaining their religious life to outsiders for decades, allowing photography and making crayon drawings of their country that look remarkably like the early paintings. Yet this generosity of exchange, or the enthusiasm of displaying one's own culture's value, has not been an easy fit with the protocols from which it emerged. And it has come to pass that many Aboriginal people came to regret their openness about their religious life, as representations of it came back in unanticipated ways to their communities - in books, films, photographs and paintings that had been meant to circulate 'outside' (at times with what appears to be consent if not successfully "informed") and not to expose local secrets within the Indigenous community. A variety of ceremonial objects, designs and performances are considered 'dear', and are sometimes 'dangerous' to show to uninitiated persons. Yet representations of precisely such forms were often present in the initial few years of the Papunya Tula painting movement, as the painters in this remote settlement did not imagine that their work would remain within the immediate sensory world of their own communities. They expected, initially, that its circulation into the whitefella domain would be exempt from local contestation. The painters were enthusiastic about their stories, and excited by the opportunities for expression offered by the new medium and by its apparent positive reception by a non-Indigenous audience. It is not surprising that they crossed some lines of Indigenous protocol in the new intercultural activity. Unlike the expressions and performances of prescribed ritual practice, individual artists typically executed paintings on their own - an activity (unlike ritual performance) that did not require the attendance and agreement of the many possible shareholders of the stories expressed.

4 By August of 1972, rumblings of dissonance began to appear in the form of criticism of the public display of stories in some of the Papunya Tula paintings exhibited at the neighboring community of Yuendumu during its well-attended "Sports weekend." As a result of the criticism of such exposure by men who shared in the ritual tradition, the Papunya artists began to drop the restricted initiatory stories of the major related Dreaming from their painting repertoire. Inappropriate disclosure of knowledge of these stories, their music or designs has customarily been punishable by death, and tales abound of women and children executed for transgression. For similar reasons, overt representation of ritual objects, too, began to be reduced or disguised - allowing for the expression of their knowledge of country, story and ritual within allowable limits.

5 In 1974, a previously established collection of early Papunya paintings was exhibited at the Residency in Alice Springs. A visiting Indigenous man was angered by what he saw, 
which was a violation of what should be shown publicly. As a result, the exhibition was taken down, and the paintings sent into storage at the Northern Territory Museum. ${ }^{2}$ In 1975, an exhibition of later paintings in Perth - $1000 \mathrm{~km}$ away - was criticized by visiting Pitjantjatjarra men who shared rights in the Tingarri Dreaming stories represented in them. While these paintings may not have transgressed the revelatory practices of initiatory restriction for Papunya Tula painters, their production and display had not recognized the rights of those from other communities who shared in the tradition. For this, a different scale of transgression, compensation nevertheless had to be made. ${ }^{3}$ In response to these continuing problems, the style of painting changed - hiding, disguising or omitting the religious objects from obvious view and focusing visually on the less dangerous ritual traditions and dimensions of the stories. Eventually, the 'problematic' early paintings were more or less secluded in a few museum collections, and their exhibition halted. In other places, where some of the early paintings might have been shown, the works may not have come to the attention of Indigenous visitors or they withheld comment rather than draw attention to what ought not to have been shown. Viewing, hearing, telling - these are serious matters in a cultural tradition where the right to know and tell are carefully guarded. Indeed, these rights are not just a matter of some kind of property; they comprise the very foundation of being, of who one is. Sharing in rights to the stories of a place means sharing a foundational identity.

6 Although the practices of painting changed to remove transgressive references, the early paintings were being exhibited in museums, circulating in the marketplace and selling at high prices at auction. By the late 1990s, photographic reproductions of the paintings were common in auction catalogues, postcards and books. [Vivien Johnson $(2010)^{4}$ provides some insight and detail into the decisions about such reproductions in catalogs, at Sotheby's for example, in an interview with Tim Klingender.]

7 It became widely known that some of the early paintings were not appropriate for exhibition, but not always which ones. For the 2000 retrospective of Papunya Tula painting at the Art Gallery of New South Wales (AGNSW), Papunya Tula: Genesis and Genius, the indigenous curator Hetti Perkins consulted with the artists of the company about the paintings she proposed to show. They cleared the paintings in the exhibition and reportedly established a principle that it was allowable to show the paintings as long as no information was provided that would identify the images. If non-Indigenous viewers saw the paintings, they wouldn't understand what they were seeing, so it would be okay to display the works: transgressive images would be hiding in plain sight. It seemed, from all this, that it might be acceptable now to show paintings containing overt religious material.

8 Recently, however, in the course of planning for the 2009 exhibition of early Papunya Tula paintings in the US for the show Icons of the Desert, and in a flurry of discussion about the collection at the Museum and Art Gallery of the Northern Territory, it became clear that this was not the case. The Northern Territory Museum is in possession of over 200 early Papunya paintings, including many of those that had been removed from the exhibition in Alice Springs in 1974. Some painters in the arts cooperative began to say that paintings with overt religious material should not be seen by the uninitiated.

In 2006, for example, at least a few of the men from Papunya Tula expressed opinions ranging from reservations about the exhibition of such images to declarative Statements 
that they ought not be shown to uninitiated people. ${ }^{5}$ Vivien Johnson initially fell upon these views accidentally in the course of another consultation, about cultural heritage, when her laptop popped open to a small image of a painting planned to be exhibited in "Icons." But the men would not discuss the issue further with her, as her status as a woman prevented that. It is clear, however, that Dick Kimber had made a number of reports over the years that indicated continued uncertainty about exhibiting certain images, although this went largely unheeded (personal communication). Nonetheless, Vivien's conversations, occurring at the same time as plans for an upcoming exhibition in the US, "Icons of the Desert," occasioned an intervention which I will discuss below. The point here is that opinions on how to treat these kinds of early paintings with restricted imagery are not consolidated; they are unstable. For example, Bobby West Tjupurrula who expressed concern to Vivien Johnson about the potential exhibition of certain images had previously spoken to me precisely of his pride at seeing a painting of his father's in the show at the AGNSW! Local Alice Springs historian Dick Kimber's consultation with relatives of deceased painters for the Icons show, instigated by me with the collectors in light of these renewed concerns, ${ }^{6}$ revealed that the principal reason for restricting access to some of the paintings with overt religious imagery was to prevent inappropriate and thus vulnerable people from the relevant Indigenous communities viewing the images. ${ }^{7}$ It was okay, almost everyone said, to show all the paintings in the US. Meanwhile, the collection of early Papunya paintings at the Northern Territory Museum has instigated a crisis of more public form. Possibly, the story here begins with the attempted theft of 6 early paintings from the Museum on April 1, 2008, brought to light the dire security and conservation condition of these works so prized elsewhere. I remember Apolline Kohen, temporarily acting director of the Museum discussing a combination of fundraising for conservation to support an international exhibition - which would have drawn attention to the value of the Museum's collection. Not too long after, in 2009, Alison Anderson - an Indigenous politician, Arts Minister of the Northern Territory, and herself from Papunya "intervened to halt plans to take the collection known as the Papunya Tula Boards on international tour in 2012, describing people who exploit sacred Aboriginal artworks as 'culture vultures"' (Lindsay Murdoch Melbourne Age 5-16-2009). As a journalist for one of the major Australian papers, Lindsay Murdoch reported,

"Controversy surrounds the collection because some of the 220 paintings show secret, sacred men's cultural ceremonies. But Ms Anderson, whose two grandfathers [e.g., Long Jack Phillipus and Ronnie Tjampitjinpa] are the only still living artists with works in the collection, has ordered a review to ensure that paintings deemed too sensitive are not exhibited" (ibid.)

So, how would this be done? Again, as reported by Murdoch (2009), Anderson said that "because she is a cultural woman, she cannot talk about the stories of the paintings, not even why they are sensitive. 'The men have to do that,' she said." The decision to halt the plans for an international tour disturbed those in Darwin - described by Murdoch as "art lovers" - who had already begun to raise funds to support it. First hand knowledge is often hard to come by, but an echo of this disturbance, resonating with the frictions between these regimes of value, can be found in Jeremy Eccles online review of the catalog of the "Icons" exhibition, which had negotiated a restriction arrangement for problematic paintings. ${ }^{8}$ It is "a complex and still muddled story," he writes.

the fate of more than a thousand Papunya boards - the genesis from which contemporary Aboriginal art sprang in 1971 - and our right to view significant public 
collections at the National Gallery of Victoria and Museum and Gallery of the Northern Territory hangs on the outcome. [Eccles 06 Sept 2009, Australian Art Review. Emphasis mine] are the authors and curators of the "Icons" material, assuming a familiar position of casting them/us as "cultural gatekeepers" (implying we might be insisting on protocols that the people themselves have left behind) or more simply as "anthropologists." Eccles "wondered whether the anthropologists were back in charge after twenty-five years of mainly aesthetic appreciation of Aboriginal art." Eccles ends his review of the catalog with a solution which, ironically, was that of the curators in the catalog:

But Northern Territory Arts Minister, former ATSIC Commissioner for the Desert and an artist herself, Alison Anderson has loudly pointed out that all those interpretations are by white people; the next step has to be to define who are the Aboriginal 'contemporary cultural custodians' of these extraordinary works. For it may well be they who decide what 'we' both see and learn in the future. [Eccles 2009]

Again, in the context of the Darwin tangle, Nicolas Rothwell, well-known art writer and Northern Territory correspondent for The Australian, also discussed the difficulties that threatened the "Icons" exhibition, and suggested that such exhibitions might be impossible in the future because of restrictions:

The wheel has turned: the images inscribed on the early boards, which emerged from concealment at a crucial point in the history of the Australian frontier, are moving back into the shadows. It is most unlikely, despite the present urgent efforts of at least two big public galleries to mount Papunya board exhibitions, that anything like informed consent from the senior custodians of the desert for their display will be forthcoming in future years. The gems of the Wilkerson collection, on view in distant gallery spaces, half a world away from the place of their creation, are not just the tokens of an artistic renaissance: they are like the pale, precious light, revealed only for a moment, that floods from the sun in eclipse. [Rothwell 2009] ${ }^{9}$

Who, then, might determine what the fate should be regarding the future exhibition of the paintings, if Alison Anderson herself could not speak? More complexly, one should imagine that broader politics had an influence as well, since Indigenous politician Marion Scrymgeour had promised the funding for conservation but now found herself in competition with Anderson. ${ }^{10}$ In the midst of this social drama, Apolline Kohen was forced out of the Northern Territory Museum. Rumor - and that is all that is available suggests that Kohen, previously a successful arts coordinator at Maningrida, had nominated herself to undertake the consultation on the Museum's collection, a role unsuitable to a woman according to Central Australian protocols and that this deeply disturbed Anderson whose cultural affiliations are at Papunya.

Since 2006, then, I have been involved in consultations about early Papunya paintings, using photographic images to discuss them. The planning of the massive National Gallery of Victoria exhibition of early Papunya paintings, in 2011, accelerated concerns for those who might lend paintings - and subsequentlly this exhibition, Tjukurrtjanu, has been shown at the Musee du Quai Branly. Now, and further, as a witness to some of the early discussions in the 1970s, along with Dick Kimber, I was one of the two people who worked on the consultation on the NT Museum collection for the review assigned to the Aboriginal Areas Protection Authority. One of the elderly Pintupi painters to whom I spoke in 2010, Ronnie Tjampitjinpa, at first told me it was okay for everybody

Les actes de colloques du musée du quai Branly Jacques Chirac, 4 | 2014 
to see the paintings: 'They are free,' he said. Then I asked him whether it would be acceptable to have these paintings exhibited in Alice Springs, where women and children from that particular Indigenous community could see them. 'No,' he said, realizing what would be involved. Then he went through a pile of photographs of his own paintings and those of his close relatives, sorting them into those that could be shown to everybody and those that women and children should not see. Indeed, at the Icons exhibition in New York University's Grey Art Gallery, we placed the nine paintings for restricted viewing in a separate area, much to the relief of two visiting Pintupi women painters. The two women had been quite apprehensive about entering the gallery, even though they wanted to see the work of their relatives, because they feared they might stumble on something inappropriate for them to see. The caution exercised with the separation of these nine paintings allowed the women a freedom of movement and the chance to follow their own protocols. ${ }^{11}$ In the case of the Icons exhibition, we felt we had been able to establish an ethical principle for private collectors, in which they might agree to respect the wishes of the Indigenous custodians of the traditions objectified in the paintings yet still exhibit work. In terms of the discussions today about "cosmology," this principle reflects the local understandings of these objects as something more than mere "commodities," as themselves extensions - iconic and indexical - of the persons and relationships they instantiate. Indeed, they continue to be understood thusly by the descendants of the painters and it is in such terms that they identify their value. Their making and exchange has always been understood, at least partly, in terms of exchanges in which people present - show and give - their identity and sacred knowledge to others and thereby enter into a relationship of recognition. To respect these terms in exhibition is not simply to engage in an abstract political correctness. Rather, it is to present these objects in their genuine complexity, to allow viewers to engage with these cultural objects as profoundly relational and to learn from them in deeper ways.

Negotiations are never settled when it comes to these paintings. Shortly, after the Icons exhibition, a far more extensive exhibition was planned at the National Gallery of Victoria, of over 200 paintings, entitled Tjukurrtjanu ("from The Dreaming"). For this, initially the curators engaged in consultation with the communities from which the paintings - produced some 40 years earlier - came. They recorded assent to their exhibition. And yet, as the time approached for the exhibition, and the results of consultations taking place for the Northern Territory Museum collection became clear, it seemed that the first consultation did not reflect the more considered opinions of custodians. This was the context of my interview with the elderly Pintupi painter I have recounted. Could it be that a consultation might be found wanting as time passed? Here remains a significant question in moving objects between what I have elsewhere called "regimes of value." 12 What are the conditions of decision-making and assent? It is assumed in museums that individuals can enter into binding contracts of agreement about conditions of exhibition, but - frequently - opinion in an Aboriginal community shifts over time, as new information comes in, as new participants speak... It is difficult to establish a final decision that is not subject to reconsideration. Indeed, these are not abstract questions. Painters and their descendants can be harshly sanctioned for decisions to exhibit or display knowledge with which others disagree, and it is quite possible that even a very thoughtful man might reconsider when he realizes more fully what a museum exhibition might entail in terms of visitors who might be offended. Recognizing this and under some pressure from me and others, on account of the 
possible harm to the Aboriginal consultants for the exhibition, the NGV agreed to follow the principle of putting the problematic paintings in a separate room.

I would like to offer you some of the terms of the spirited discussion I had with various people involved in the NGV Tjukurrtjanu exhibition. What was the problem, you wonder? For their part, the curators were committed to a "fine art" or "art historical" display, attending to the formal qualities of the works by showing them in seriation and grouped by artist. To remove "key" works, or even to place them elsewhere, challenged this principle - the art equals aesthetics principle echoed in the citations I have offered from the critics Eccles and Rothwell. Despite their long and respectful association with Indigenous people in Central Australia, some of the curatorial group felt that the time of this gender-based segregation was or should be over, that things had changed and perhaps observing of this principle was more a form of political correctness on the part of white gatekeepers than it was initiated by the Indigenous community itself. Here, we might read again the concerns articulated by Jeremy Eccles, but now emanating from people who have had closer relationships with producing communities. Do we see here a reduction of accountability with temporal and spatial distance from the community? Second, the question was raised as to whether a public museum or art gallery could restrict any citizens from access to viewing. Finally, members of the community had agreed to the exhibition and had signed releases. But, as I learned later, the request for permission was accompanied by the lure of checks at hand and undertaken with video recording. Well-intentioned it might be to offer compensation and to provide a sincere record, but one can see another side as well. Let me underscore how hard it is to ascertain what "informed consent is in such complex situations where people may not have thought through the consequences or contexts of exhibition. Additionally, Indigenous participants, at least in Central Australia, are reluctant to refuse those they know, something that curators eager to show work may unwittingly exploit. The curators' desire to show paintings -- using the comprehensive collection to display an art historical series as a formal aesthetic exploration would be a coup for them -- is experienced as pressure on the part of cultural custodians. To this, one has to answer with a concern for possible harm or retaliation to the custodians. But not only, I think. There is also the question of what is the purpose of an exhibition. If it is to engage viewers with the complexity of these objects, their wonder and mystery, why try to erase it? Why not build these questions into the exhibition itself? This would be a more conceptual dimension and one that acknowledges the actual history of these paintings.

What have we learned, then? I think we have realized that some of the early Papunya paintings remain dangerous or problematic for open exhibition, particularly for those who are their custodians. Consultation is necessary in order to determine how the relevant local custodians of the traditions evaluate the suitability of exhibition. These consultations need to be careful and extensive, allowing for discussions and for views to change as those consulted consider other relevant shareholders. In 1975, for example, the Pintupi painters of the Tingarri stories had rights to those stories, but their Pitjantjatjarra neighbors also had rights, and the two groups disagreed about the suitability of showing these stories. Thus, we need to acknowledge that while the painters and their descendants are custodians and authorities for the stories that were depicted, there may be others who share the rights to these stories - and they may have different views. Perhaps the adult child of a deceased artist thinks it is all right to show a certain work painted by his father, but what if he hasn't imagined what will happen when a visitor from a related Indigenous community visits the gallery? Having 
written of this myself, and following also the work of Ken Liberman of years ago, what is the status of a "decision" in Western Desert protocol? How do the determinations of a present group hold authority in the technologically and socially transformed current condition? It is an old rabbinic tradition, and a more general moral one, that if there is any uncertainty or ambiguity, one should err on the side of caution. This is an inescapably difficult issue. When seeking agreements for an exhibition, curators need to acknowledge the internal politics of custodianship and find ways to present the paintings that respect the complexities of Indigenous protocols. This also means respecting the temporalities and openness of the negotiations in which the custodians and other stakeholders engage.

Having made my somewhat truncated argument for the necessity of ongoing negotiation, rather than a punctuated consultation and agreement - a position I regard as crucial to the real goals of cultural property claim (contra Michael Brown), I would like to suggest very briefly why there might also be value in finding a way to include some restricted paintings in the inventory of exhibition. I need to return to Alison Anderson, as she has returned to this question very recently with the handing over of the consultation report, on which I worked, to the NT Museum. In this report, 66 paintings were regarded as inappropriate for exhibition, and the consultants have further asked that the reasons for their restriction not be available publicly. They did agree that senior men could give permission to appropriate outside men to view the paintings.

19 In a moving speech at the exhibition of locally held works from Papunya Tula at the Alice Springs Araluen Gallery, Anderson took the opportunity to re-State her view, calling "on those who love the art to be happy with its 'beautiful surface', to not try 'to see behind the veil', to not delve into its 'inner secrets"' (Alice Springs News Online $11 / 17 / 12) .{ }^{13}$ For Anderson,

This is an exhibition about my home, Papunya, and my law and culture, and about my youthful years, when I sat with all my dear fathers and uncles and grandfathers, and watched them as they painted the first boards and early canvases in Papunya and its camps. There are works here from recent years, by artists who are still among us, artists from Kintore and Kiwirrkurra.

But it is also an exhibition about Alice Springs, the town that first saw and appreciated and loved western desert art. These paintings you see all around you are the collections of the town, its councils and its men and women. This exhibition is a bridge between these two worlds: a precious bridge.

It is also a window into the past - a past I see very clearly, with the eyes of childhood. I see once more the painters from the early days, and you can walk around and see their works here on the walls, and feel something of their character, their wisdom and their grace.

These are the people who taught me how to live, they taught me my culture. The heart and core of every western desert man and woman is on view in these galleries. I see the first painters in my mind's eye so clearly: Old Mick Wallangkari Tjakamarra, and Johnny Warrangkula Tjupurrula, and old Shorty Lungkata Tjungurrayi. ${ }^{14}$

For those of us without Anderson's depth of experiential knowledge, how are we to understand the dynamic of this art form, even to comprehend its surface, which became what it was and what it is through engagement with boundaries, challenges, threats as the inspiration of a secreted religious life found expression in new form. Perhaps these are reasons simply to keep the collection, keep its knowledge, in storage for now, or to figure out a way to allow some of this dynamic to be seen. Moreover, as I 
have argued elsewhere, the dynamics of revelation and concealment are intrinsic to the tradition from which these paintings emerge. Painters played at the edge of these boundaries, as they no doubt did in deciding when and what to reveal in ceremonies sometimes with unfortunate consequences. But curators must be mindful, indeed accountable, of and to those who will bear the responsibilities of revealing the work. For it to be "art," in the way that Eccles desired, something has had to be stripped away in translation.

21 At the same time, for us to recognize them for as Anderson does - as objects with a special cultural history - one needs some sort of exhibitionary strategy that respects the problem of translation or more importantly one that incorporates the genuine challenge these objects offer to the very limited frameworks of Western contemporary art that, ironically, are espoused by critics like Eccles and, at times, Rothwell. I know, and would be happy to discuss, the history of the interventions on Western knowledge and viewing practice that have surfaced in cultural and intellectual property cases Gould at Warburton, Mountford and the Pitjantjatjarra, Wandjuk Marika and cultural copyright - but the unsettling continues and nowhere with more force than in the Pitjantjatjarra homelands. Rothwell has recently written of the Pitjantjarra painters like Hector Burton who (rather recently) "formed a plan" for new paintings that be a "gateway into traditions and stories, but they were a barrier as well' (Rothwell $1 \mathrm{March}$ 2012a, "Trees hide secrets endangered by success"). ${ }^{15}$ They would protect their stories from curious outsiders, by using something other than the so-called traditional icons -not sacred rockholes and patterns in the landscape but trees. Rothwell traces this concern (not a new one) to meetings and discussions in 2011 among senior men "synoptic thinkers" and "political leaders, as he describes them, -- who made a decision to shift away from "old icons" of religious life. In their place, the painters of Amata have produced canvasses "that initiate and embody an art of concealment: that seek to turn the recent tide of revelations about desert beliefs" (Rothwell March 1, 2012b: "Mysteries of Desert Kings stay concealed among the trees"). ${ }^{16}$ While the practice of concealment, I have argued repeatedly (Myers 2002, 2012, nd), lies at the core of Western Desert art, what is the occasion for this announcement of it as a novelty by Rothwell? It is contemporaneous, by the way, with a series of local denunciations and blockings of research projects already apparently negotiated by well-established researchers - such as Diana James's Songlines Project with the National Museum of Australia, and (or so I have heard) Ute Eickelkamp's research at Ernabella. I have to leave that question now, wondering about the current conflicts between art centres/art advisers or possibly journalists and art critics and anthropological research, a conflict that has some resonance with Rothwell's long program of claiming to rescue "art" from "anthropology." I know that many on the scene regard these articles and the events in these communities to reflect some emerging politics surrounding knowledge, following on criticisms of independent art centres and support of private dealers, but we cannot imagine that the practice of consultation and negotiation will be - or can be separated from the currents that roil contemporary life in Indigenous Australia.

In undertaking to display this extraordinary early history of Papunya Tula Artists, its outburst of creativity and intensity of attachment to place and tradition in paint, the curators of Tjukurrtjanu at the NGV - and now at the musée du quai Branly -- have recognised how the perspectives of western curatorial and Indigenous authority can clash. I believe these institutions and Papunya Tula Artists, have taken the respectful 
path in consultation and exhibition - true to the complexities of the work - by placing the paintings that might concern Indigenous viewers in a separate area, together with a caution for those who identify themselves as subject to the protocols of the Indigenous communities of Central Australia. Certainly, the most "dangerous" of the paintings are not being shown at all. Perhaps this determination will prove unsatisfactory over time, but it is true to the epistemology and politics of knowledge that continue to define the intersection of Indigenous and Euro-Australian regimes of value.

\section{NOTES}

1. See Fred Myers, 'Truth, beauty, and Pintupi painting', Visual Anthropology, vol. 2, no. 2, 1989, pp. 163-95.

2. See Vivien Johnson, Once Upon a Time in Papunya, University of New South Wales Press, Sydney, 2010.

3. See R. G. Kimber, 'Politics of the secret in the contemporary Western Desert', in C. Anderson (ed.), Politics of the Secret, Oceania Monograph 15, University of Sydney, Sydney, 1995, pp. 123-42; and F. Myers, Painting Culture: The Making of an Aboriginal High Art, Duke University Press, Durham, 2002.

4. Vivien Johnson, ibid.

5. Vivien Johnson has reported on these 2006 conversations in Once Upon a Time in Papunya (2010).

6. These events are discussed in more detail in two articles I have written, "Censorship from Below: Aboriginal Art in Australian Museums," In T. Berman, ed., No Deal! Indigenous Arts and the Politics of Possession. Santa Fe, NM: SAR Press, 2012, pp. 174-187; "Showing too much, showing too little: predicaments of painting Indigenous presence in Central Australia," In G. Penny and L. Graham, eds., The Performance of Indigeneity Lincoln: Univ of Nebraska Press. Forthcoming.

7. R. G. Kimber, 'Relatives of the artists respond to the paintings', in R. Benjamin (ed.), Icons of the Desert: Early Aboriginal Paintings from Papunya, Cornell University Press, New York, 2009, pp. 71-6. 8. Jeremy Eccles, "Icons of the Desert," Australian Art Review (online). 6 September 2009.

9. Nicolas Rothwell, "From the Desert, Artists Came." The Australian (online), 13 February 2009.

10. In her role as Arts Minister of the Northern Territory, Alison Anderson cancelled an exhibition of these paintings, contravening an election promise by Scrimgeour who had proposed $\$ 300,000$ to restore and show the paintings (Calacouras, "Secret Art Business Stirs Pot on Public Exhibition," 05-20-09 Northern Territory News). Calacouras notes that Apolline Kohen, then acting director of MAGNT, had been supervising the exhibition, but "was removed from her job shortly after Ms Anderson intervened." He reports that she might have been "removed after a series of 'ideological differences', in particular relating to the Papunya show."

11. I have presented a fuller discussion of these issues and the significance of new protocols in an essay that is not yet published. See Fred Myers, 'Showing too much, showing too little: predicaments of painting Indigenous presence in Central Australia', in G. Penny \& L. Graham (eds), The Performance of Indigeneity, forthcoming.

12. By a regime of value, I speak of a hierarchical structure of values of the sort discussed by Louis Dumont. Such a structure can incorporate apparently contradictory values within a framework of encompassment rather than one of simple logical resolution.

13. Alice Springs News Online $11 / 17 / 12$ 
14. Alison Anderson quoted ibid. 11/17/12.

15. Nicolas Rothwell, "Trees hide secrets endangered by success." The Australian (online) 1 March 2012a,

16. Nicolas Rothwell, "Mysteries of Desert Kings stay concealed among the trees." The Australian (online) March 1, 2012b:

\section{AUTHOR}

\section{FRED MYERS}

New York University 